\author{
Huseynov Ilkin Adil, \\ Azerbaijan State University of Economics (UNEC), Azerbaijan \\ ORCID ID, 0000-0002-2665-7858 \\ email: ihuseynov@gmail.com \\ Illiashenko Tetiana, \\ Ph.D., Sumy State University, Ukraine \\ iD ORCID ID, 0000-0002-4461-7534 \\ email: t.illyashenko@finance.sumdu.edu.ua \\ Petroke leva, \\ Kaunas University of Technology, Lithuania \\ (iD) ORCID ID, 0000-0001-8937-1219 \\ email: ieva.petroke@gmail.com
}

Correspondence author: ihuseynov@gmail.com

\title{
MANAGEMENT OF INNOVATION DEVELOPMENT: CRITICAL EVALUATION OF THE INTERNATIONAL ECONOMIC RELATIONS
}

Abstract. The problem of the geopolitical stability of the country has always been the basis of sustainable economic development. CIS countries and their closest neighbours are the international centres where important transport and communication routes from Asia to Europe intersect. They have a wide range of various raw material reserves, which focuses the world community's attention and builds a separate vector of economic relations. The transformation processes that have taken place in recent years in countries have been due to scientific and technological progress, the intensity of global innovation, and globalization trends, which encourage the country to move to a new level of development. This article summarizes the arguments and counterarguments within the scientific discussion on the place and prospects of CIS countries' international economic position in the formation of the basis for innovative development. The main purpose of the study is to confirm the hypothesis about the functional links between foreign trade and investment activities of countries and the level of innovative development of the country according to the level of economical development. The study's methodological tools were the methods of correlation-regression analysis and simultaneous structural equations, which allow formalizing both explicit and latent relationships between the studied objects. The study period was chosen from 2011 to 2018 because of statistical data availability. In this regard, the array of input data is presented in the form of regressors which identify the level of innovation development countries and three dependent variables (regressands) which indicate the dynamics of foreign trade turnover, doing business and total internal economic conditions. Besides, the variables from each defined block participate as both dependent and independent variables during the construction of the structural model. The results of the study could be useful for The Innovation Agencies, which are established under the Ministry of Transport, Communications and High Technologies of these countries that assist local business entities in acquiring modern technologies and technological solutions.

Keywords: international economic relations, investments, export, import, foreign trade turnover, CIS countries, regression analysis, structural modelling.

Introduction. The relationship between international economic activity and innovative development is the only vector in the mutual reinforcement of the economic stability of the country. The organization of a global network of value streams, border management, international trade relations, investment flows

Cite as: Huseynov, I. A., Illiashenko, T., \& Petroke, I. (2021). Management of Innovation Development: Critical Evaluation of the International Economic Relations. Marketing and Management of Innovations, 1, 266277. http://doi.org/10.21272/mmi.2021.1-20 266 
and industrial policy are fully conditioned by the willingness of society to engage in innovation processes. Research and production activities are increasingly becoming transnational. More and more countries worldwide need to introduce and adopt new technologies and develop the innovative capacity to effectively address sustainable development issues, including the environment, food and food production, safety and health. Global rules of digital trade; a set of rules to expand the search for new innovative opportunities; updated rules of internationally agreed and targeted research in areas that recognize global public concern; coherence of steps to establish international standards based on open and global cooperation - all this contributes to the reform of the international economic space. Despite the urgency of this issue, in many countries, there is a problem of establishing coherence between the level of innovation development and international economic activity. Effective management of both components is an essential prerequisite for the country's macroeconomic stability. It determines the country's external position on readiness to engage in an international network of digital technologies.

Literature review. The international positioning of countries today largely depends on the degree of «innovation» of all spheres of human activity. The innovative development of the country is largely determined by the general level of education of the population. Today, new methods used during training are being updated. In particular, one of such innovative methods is dual education. This trend is actively developing in Ukraine in collaboration with leading countries, such as Germany (Buchynska et al., 2020), Central and Eastern Europe (Strielkowski \& Höschle, 2016; Kharazishvili et al., 2020; Vorontsova et al., 2020). Speaking of international integration, it is no longer enough to operate only with traditional tools and communication channels. The tendency to actively use artificial intelligence and big data underlie the functioning of the country's economy in a global sense. The place and role of business intelligence in making important management decisions are discussed in the works of Rausser et al. (2018), Delanoy and Kasztelnik (2020), Goncharenko (2020), the use of Internet technology in the formation of leadership qualities of the younger generation, which forms the basis for sustainable development of the country, it is said in the works of Ahmmed and Salim (2019), Bardy and Rubens (2019), Kwilinski \& Kuzior (2020), a team of authors led by Yarovenko et al. (2020). The introduction of the principles of innovative leadership in the process of public management (Akimova et al., 2017; Kasztelnik and Brown, 2020; Akimova et al., 2020; Lyulyov et al., 2021; Ibragimov, 2019a, 2019b) forms the basis for the development of international economic relations. Samoilikova (2020) examines the key factors of innovation development based on the specifics of shaping the country's financial policy: Among the following factors are those related to international economic activity: the amount of research work with funding from foreign sources, as well as direct foreign investments. Thus, in the works of Marcel (2019) on the example of the Republic of Benin and Agnihotri and Arora (2019) on the example of India, foreign direct investment is seen as a decisive factor in economic growth. The macroeconomic stability of the country is a complex category and is formed based on internal activities and external economic relations of the country. The group of indicators of the category of stimulants, disincentives and nominators that underlie the definition of an integrated indicator of macroeconomic stability of EU countries is discussed in detail in scientific articles Zolkover and Renkas (2020), a group of authors led by Brychko et al. (2020), a group of authors led by Vysochyna et al. (2020), Bilan et al. (2019a; 2019b), Tiutiunyk (2018). The COVID-19 virus (Kuzmenko et al., 2020) has become an unconditional factor that has also made its adjustments in conducting international business.

The activities of small and medium-sized businesses and, in particular, the financial and innovative strategies of enterprises in the five-year perspective have a positive qualitative effect on the development of both social and economic spheres (Kuznyetsova et al., 2019; Umadia and Kasztelnik, 2020; Myroshnychenko et al., 2019). Besides, one of the scientific papers (Gatsi, 2020) examines the impact of international remittances on the level of financial inclusion of Ghana's population. It was found that the intensification of the flow of international remittances increases the number of open bank 
accounts and the quality of banking services (Leonov et al., 2018; Lyeonov et al., 2020). Budget management's effectiveness as the basis of public financial management is widely disclosed in the world scientific community. Particular attention in scientific works is given to jobs in the formation of a system of international economic relations between countries, taking into account the geopolitical situation. Thus, the specifics of international trade between Cuba and the United States (Mujtaba et al., 2019), given the political tensions and the political system of the countries, built in such a way that each counterparty gets the most out of foreign economic activity. China plays a crucial role in shaping the international economic policy of all countries, so it is appropriate to pay attention to the research of Chinese scientist Shuquan, who in his work (Shuquan, 2018) on the evaluation of the transmission mechanism of international pricing of Chinese food products.

Despite numerous studies, the relationship between the critical determinants of international economic activity and its innovative development has received insufficient attention. It determines the formation of this study's next goal - to confirm the hypothesis about the functional links between foreign trade and investment activities of countries and the level of innovative development of the country according to economic growth.

Methodology and research methods. Despite the territorial proximity, as well as long-term cooperation within one country, the CIS member states, as well as the nearest neighbouring countries today, have significant differences in economic development. In particular, the leading indicator of the level of economic growth is usually GDP. Analyzing the state of GDP per capita in 2019 for a specific sample of countries, and the value of the innovation index (Fig. 1), we see significant heterogeneity: from 1724.84 thousand dollars in Uzbekistan, up to 11585 thousand dollars in Russia, GDP per capita and from 24.5 in Uzbekistan and 36.3 in Ukraine innovation index.

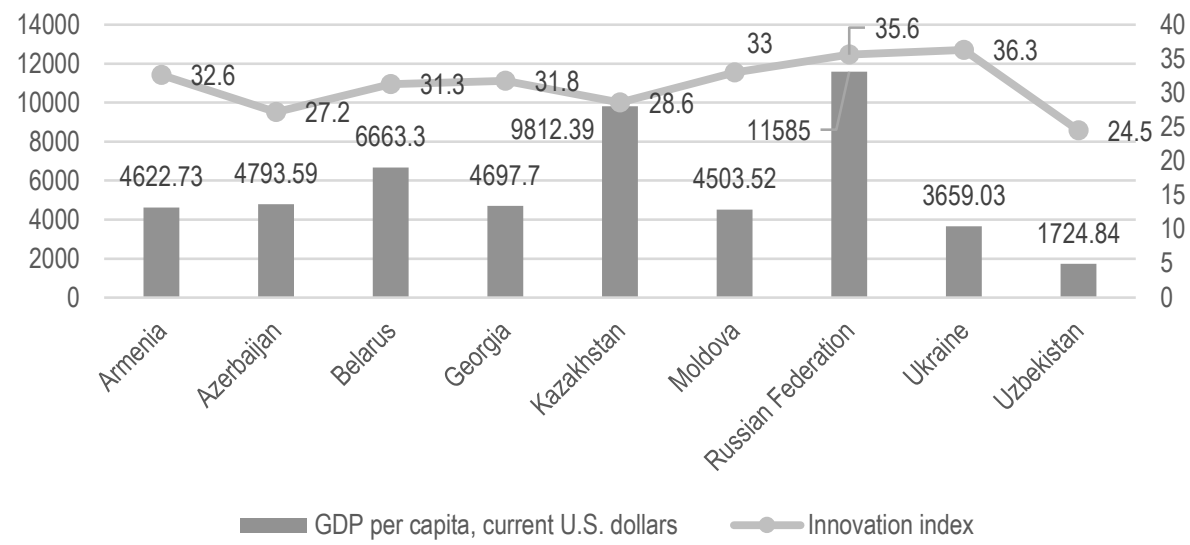

Figure 1. GDP per capita for CIS member states and neighbouring countries in 2019, U.S. dollar Sources: developed by the authors based on data from The Global Economy.

Given this difference and the unstable geopolitical situation in the studied countries, we can make assumptions about significant differences in international economic activity. One of the indicators used to assess the country's openness is Trade openness, which is defined as the share of total exports and imports of GDP. The following graph (Fig. 2) on the X-axis shows Trade openness. On the Y-axis Global innovation index, the balls' area is correlated with the level of GDP in this country. 
I. A., Huseynov, T., Illiashenko, I., Petroke. Management of Innovation Development: Critical Evaluation of the International Economic Relations

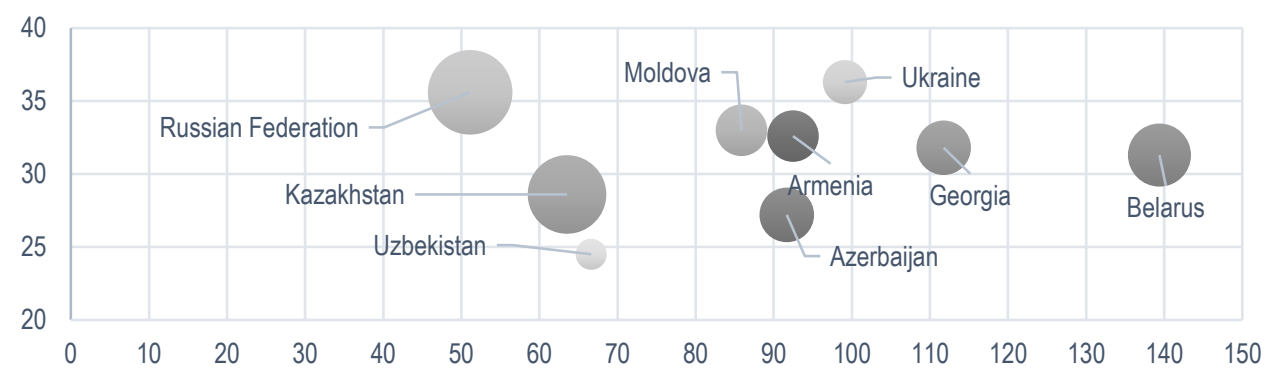

Figure 2. Trade openness $(\mathrm{X})$ and Global innovation index $(\mathrm{Y})$ of $\mathrm{ClS}$ countries and their closest neighbours in 2018 (bubbles sized by GDP per capita)

Sources: developed by the authors based on data from The Global Economy.

As you can see, despite the highest level of GDP per capita in Russia, the share of trade balance in GDP of this country is the lowest compared to other countries, but in terms of innovation, Russia is one of the leaders. Ukraine is significantly ahead of Russia and other countries in terms of Trade openness and Global innovation index but lags behind Belarus, which leads this group of countries. Thus, the country's level of economic development is not a key reference point for the innovative development of the country and the establishment of international economic relations, which cannot be said about the relationship between the last two categories.

The study of the interaction between the level of innovation development and the international economic activity of the country was conducted using the statistical package STATA 13 , and, in particular, the built-in module Longitudinal/panel data, which allows processing panel data, and special operators xtreg and areg, SEM (structural equation modelling), which will enable you to build a system of structural equations, and Factor and principal component analysis, which is used to select the most relevant indicators.

Structural modelling, as one of the methods of economic-mathematical modelling, allows revealing implicit connections between the studied structural structures of data. The key advantages of using structural modelling to identify functional relationships between variables are:

- flexibility and complexity of the methodology, which allows establishing a logical connection between different categories of research (theoretical and empirical);

- the possibility of simultaneous construction of multifactor models with convenient graphical visualization of functional dependencies;

- multilevel criterion system for checking the adequacy of the model, which allows identifying problem areas;

- elimination of multicollinearity in the model.

As a result of using structural modelling, a system of linear regression equations of the following form is formed (1).

$$
\begin{aligned}
& A=a_{11} x_{1}+a_{12} x_{2}+\cdots+a_{1 n} x_{n}+\varepsilon_{1}, B=b_{21} A+a_{21} x_{1}+a_{22} x_{2}+\cdots \\
& +a_{2 n} x_{n}+\varepsilon_{2}, C=b_{31} A+b_{32} B+a_{21} x_{1}+a_{22} x_{2}+\ldots+a_{2 n} x_{n}+\varepsilon_{2},
\end{aligned}
$$

where $A, B, C$ - endogenous variables, $x_{n}$ - exogenous variables, $a_{m n}$ and $b_{m n}$ - regression parameters, $\varepsilon$ - residual component of the study.

Endogenous variables, in this case, play the role of latent (implicit) variables that describe a particular phenomenon or area. Graphical representation of the specification of the structural model 
involves the construction of a path diagram, which determines the structure of functional relationships between explicit and implicit variables. It allows giving a clear understanding of the nature and heterogeneity of the model and thus simplifies the process of entering the model's parameters. Therefore, the conditional graphical representation of any structural model has the following form (Fig. 3).

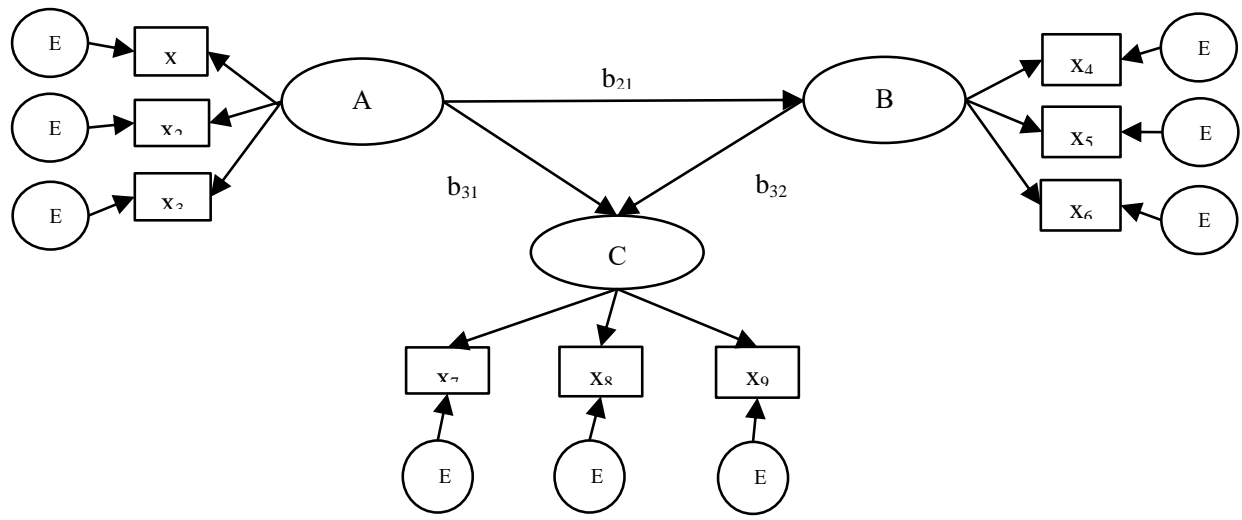

Figure 3. Graphical representation of functional relationships between explicit and latent variables

Sources: developed by the authors.

The content of the obtained parameters of the regression equations is described as follows (2).

$b_{21}: A=>B$ (direct effect) $b_{32}: B=>C$ (direct effect)

$b_{31}: A=>C$ (direct effect) $b_{21}{ }^{*} b_{32}: A \Rightarrow C$ (indirect effect)

$b_{31}+b_{21} * b_{32}: A=>C$ (total effect $)$,

A set of panel data from several indicators was formed to test the hypothesis of identifying a significant link between the country's innovative development and its international economic activity. A total of 9 countries are involved in the study, some of which are part of the CIS (Union of Independent States). Some are close neighbours of these countries: Armenia, Azerbaijan, Belarus, Georgia, Kazakhstan, Moldova, Russia, Ukraine, Uzbekistan. The study period covers 2011-2018. All input data are obtained from the databases the World DataBank Global Financial Development and The Global Economy.

Let's consider in more detail the structure of indicators that were taken into consideration. A total of twenty-one indicators are involved in the study, six of which (INNOV group) describe the level of innovative development of the studied countries (Innov1-Innov6), twelve (INTER group) - various areas of international economic activity (Inter1-Inter12) and three (GOV group) - general economic condition of countries (Gov1-Gov3). Table 1 presents in more detail all of these indicators.

Table 1. The array of input data

\begin{tabular}{ccl}
\hline $\begin{array}{c}\text { Indicator } \\
\text { symbol }\end{array}$ & Indicator name & \multicolumn{1}{c}{ Indicator content } \\
\hline Innov1 & Innovation index & $\begin{array}{l}\text { Ranking the world's countries and economies through innovational } \\
\text { measures, environments, and outputs. }\end{array}$ \\
\hline
\end{tabular}


I. A., Huseynov, T., Illiashenko, I., Petroke. Management of Innovation Development: Critical Evaluation of the International Economic Relations

\begin{tabular}{|c|c|c|}
\hline & & Continued Table 1 \\
\hline Innov2 & $\begin{array}{l}\text { Research and } \\
\text { development } \\
\text { expenditure }\end{array}$ & $\begin{array}{l}\text { Expenses are associated directly with the research and development of a } \\
\text { company's goods or services and any intellectual property generated in } \\
\text { the process, per cent of GDP. }\end{array}$ \\
\hline Innov3 & $\begin{array}{l}\text { Information } \\
\text { technology } \\
\text { exports }\end{array}$ & $\begin{array}{l}\text { Computers and peripheral equipment, communication equipment, } \\
\text { consumer electronic equipment, electronic components, and other } \\
\text { information and technology goods (miscellaneous), per cent of total } \\
\text { goods exports. }\end{array}$ \\
\hline Innov4 & $\begin{array}{l}\text { High technology } \\
\text { exports }\end{array}$ & $\begin{array}{l}\text { Products with high R\&D (research and development) intensity: } \\
\text { aerospace, computers, pharmaceuticals, scientific instruments, and } \\
\text { electrical machinery, mln UD dol. }\end{array}$ \\
\hline Innov5 & $\begin{array}{l}\text { High technology } \\
\quad \text { exports2 }\end{array}$ & $\begin{array}{l}\text { Products with high R\&D (research and development) intensity: } \\
\text { aerospace, computers, pharmaceuticals, scientific instruments, and } \\
\text { electrical machinery, per cent of manufactured exports. }\end{array}$ \\
\hline Innov6 & $\begin{array}{l}\text { Patent } \\
\text { applications by } \\
\text { residents }\end{array}$ & $\begin{array}{l}\text { Cash payments for operating activities of the government in providing } \\
\text { goods and services. }\end{array}$ \\
\hline Inter1 & Import & $\begin{array}{l}\text { The value of all goods and other market services received from the rest of } \\
\text { the world (merchandise, freight, insurance, transport, travel, royalties, } \\
\text { license fees, and other services), bln US dol. }\end{array}$ \\
\hline Inter2 & Export & $\begin{array}{l}\text { The value of all goods and other market services provided to the rest of } \\
\text { the world (merchandise, freight, insurance, transport, travel, royalties, } \\
\text { license fees, and other services), bln US dol. }\end{array}$ \\
\hline Inter3 & Trade openness & Exports plus imports as per cent of GDP. \\
\hline Inter4 & $\begin{array}{l}\text { Foreign Direct } \\
\text { Investment }\end{array}$ & $\begin{array}{l}\text { The net inflows of investment to acquire a lasting management interest, } \\
\text { per cent of GDP. }\end{array}$ \\
\hline Inter5 & $\begin{array}{l}\text { Foreign Direct } \\
\text { Investment2 }\end{array}$ & $\begin{array}{l}\text { The net inflows of investment to acquire a lasting management interest, } \\
\text { billion USD. }\end{array}$ \\
\hline Inter6 & $\begin{array}{l}\text { Net portfolio } \\
\text { equity inflows }\end{array}$ & Net inflows from equity securities, mln US dol. \\
\hline Inter7 & $\begin{array}{l}\text { Current account } \\
\text { balance }\end{array}$ & $\begin{array}{l}\text { The sum of net exports of goods and services, net primary income, and } \\
\text { net secondary income, per cent of GDP. }\end{array}$ \\
\hline Inter8 & $\begin{array}{l}\text { Current account } \\
\text { balance2 }\end{array}$ & $\begin{array}{l}\text { The sum of net exports of goods and services, net primary income, and } \\
\text { net secondary income, billion USD. }\end{array}$ \\
\hline Inter9 & Trade balance & $\begin{array}{l}\text { Exports of goods and services minus imports of goods and services, per } \\
\text { cent of GDP. }\end{array}$ \\
\hline Inter10 & Trade balance2 & $\begin{array}{l}\text { Exports of goods and services minus imports of goods and services, } \\
\text { billion USD. }\end{array}$ \\
\hline Inter11 & $\begin{array}{l}\text { Foreign exchange } \\
\text { reserves }\end{array}$ & $\begin{array}{l}\text { Holdings of monetary gold, special drawing rights, reserves of IMF } \\
\text { members held by the IMF, and holdings of foreign exchange under the } \\
\text { control of monetary authorities, billion USD. }\end{array}$ \\
\hline Inter12 & External debt & $\begin{array}{l}\text { Debt owed to nonresidents repayable in currency, goods, or services, per } \\
\text { cent of GNI. }\end{array}$ \\
\hline $\begin{array}{l}\text { Gov1 } \\
\text { Gov2 }\end{array}$ & $\begin{array}{l}\text { GDP per capita } \\
\text { Inflation }\end{array}$ & $\begin{array}{l}\text { Per capita gross domestic product, current U.S. thous dollars. } \\
\text { The consumer price index, annual } \% \text {. }\end{array}$ \\
\hline Gov3 & Real interest rate & $\begin{array}{l}\text { The lending interest rate adjusted for inflation as measured by the GDP } \\
\text { deflator, } \%\end{array}$ \\
\hline
\end{tabular}

Sources: developed by the authors based on data of The Global Economy and World Bank.

To select the most critical indicators from the first two groups, we use principal components. According to the graph of the stony rash criterion (Fig. 4), a sharp decline in eigenvalues occurs in the first four components, after which the graph decreases more smoothly. Therefore, based on precisely 
I. A., Huseynov, T., Illiashenko, I., Petroke. Management of Innovation Development: Critical Evaluation of the International Economic Relations

four components, the cumulative variance of $82.5 \%$, the choice of indicators that will participate in the structural modelling will be made.

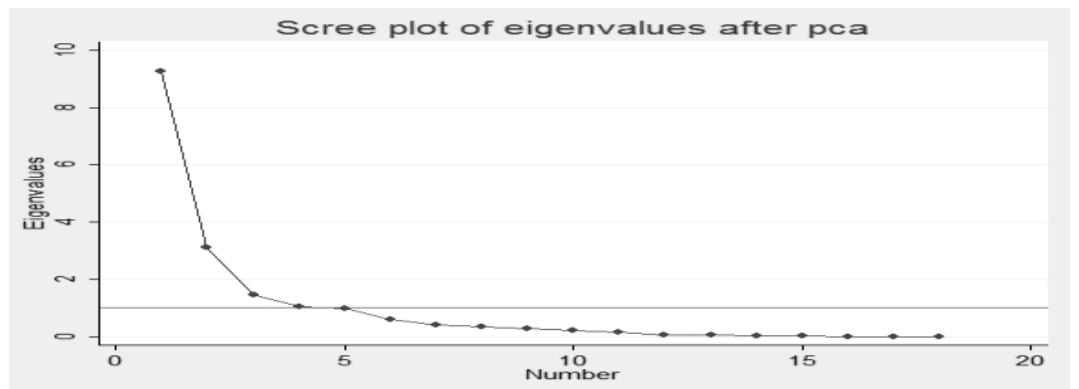

Figure 4. Scree plot of eigenvalues after PCA

Sources: developed by the authors.

Given the factor load of indicators (Table 2), the highest correlation value in each of the studied groups of indicators belongs to Innov1 (Innovation index), Innov3 (Information technology exports), Innov5 (High technology exports2), Inter3 (Trade openness), Inter9 (Trade balance) and Inter12 (External debt). These indicators, as well as the three indicators that characterize the general economic development of countries, will participate in structural modelling.

Table 2. Factor loads $(>0,3)$

\begin{tabular}{ccccc}
\hline Indicator symbol & Component 1 & Component 2 & Component 3 & Component 4 \\
\hline Innov1 & & 0,4329 & \\
Innov2 & & 0,4303 & 0,3388 \\
Innov3 & 0,3055 & & & \\
Innov4 & & 0,7458 & \\
Innov5 & 0,3215 & & \\
Innov6 & 0,3217 & & \\
Inter1 & 0,3251 & 0,3137 & 0,5534 \\
Inter2 & & & \\
Inter3 & & & \\
Inter4 & & $-0,4208$ & 0,3773 \\
Inter5 & & & \\
Inter6 & & & \\
Inter7 & & & \\
Inter8 & & & \\
Inter9 & & & \\
Inter10 & & & \\
Inter11 & 0,3165 & 0,5069 & \\
Inter12 & 0,3230 & 0,3742 & \\
\hline
\end{tabular}

Sources: developed by the authors.

We introduce three latent variables, the schematic representation of which is also presented in Figure 5:

- INNOV: Innovation index, Information technology exports, High technology exports2;

- INTER: Trade openness, Trade balance, External debt:

- GOV: GDP per capita, Inflation, Real interest rate. 
I. A., Huseynov, T., Illiashenko, I., Petroke. Management of Innovation Development: Critical Evaluation of the International Economic Relations

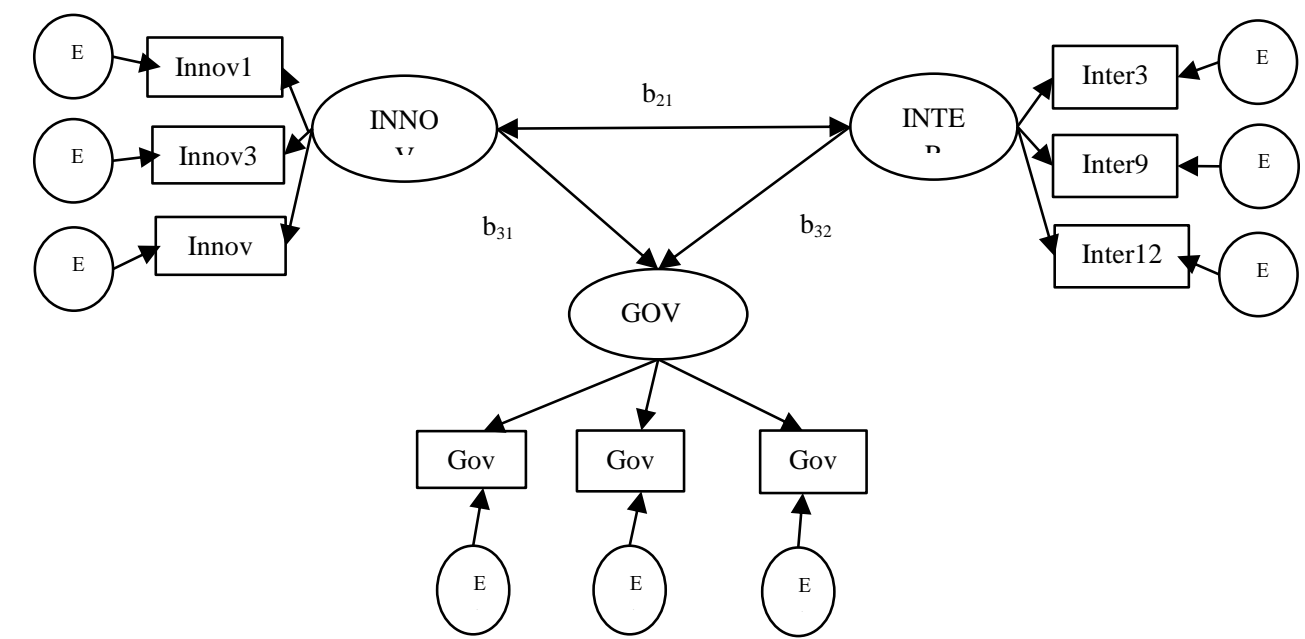

Figure 5. Graphical representation of functional relationships between explicit and latent variables when assessing the relationship between the level of innovation development and

Sources: developed by the authors. international economic activity

As a result of structural modelling, the following regression parameters were obtained (Table 3). Depending on the direction of connection between the latent variables INNOV and INTER (depending on the moment, these variables are exogenous or endogenous to each other), different regression parameters were obtained. However, all the determining parameters are statistically significant because the $p$-level for all values is less than 0.05 . The model is also qualitative, which is confirmed by the importance of the maximum cosine residue criteria and the RMS index, close to zero, and the compliance of residues' distribution with the customary distribution law.

Table 3. The results of structural modelling, reflecting the functional relationship between the level of innovation development and international economic activity

\begin{tabular}{cccc}
\hline Direction of communication & Parameter & t-test & p-level \\
\hline INNOV=>INTER & 13,147 & 4,187 & 0,000 \\
INNOV=>GOV & 4,556 & 6,906 & 0,000 \\
INTER=>GOV & $-0,269$ & $-4,613$ & 0,000 \\
INTER=>INNOV & 2,583 & 4,782 & 0,000 \\
INTER=>GOV & $-4,748$ & $-6,234$ & 0,000 \\
INNOV=>GOV & 1,312 & 5,897 & 0,000 \\
\hline
\end{tabular}

Sources: developed by the authors.

In the second stage of the study, we construct a multifactor linear regression model of the form (3-4) with random effects, where the dependent variables will be three indicators, INTER groups, which participated in structural modelling and identify the level of international economic relations of the studied countries. as regressors - six indicators of innovative development.

$$
y_{i t}=\alpha+X_{i t}^{*} \beta+v_{i t}, i=1, \ldots, N ; t=1, \ldots, T,
$$

where $i$ - serial number of the object of study; $t$ - research period; $\alpha$ - free member; $\beta$ - vector of dimensional coefficients $\mathrm{K}^{\times} 1 ; \mathrm{X}_{i t}^{*}$ - vector-row matrix $K$ of explanatory variables; $v_{i t}$ - regression error. 
I. A., Huseynov, T., Illiashenko, I., Petroke. Management of Innovation Development: Critical Evaluation of the International Economic Relations

$v_{i t}=u_{i}+\varepsilon_{i t}$

where $u_{i}$ - individual effects of observations; $\varepsilon_{i t}$ remnants of the model.

Tables 4-6 presents the result of three models.

Table 4. The results of a regression model with random effects, which reflects the functional relationship between the level of innovative development of countries and Trade openness

\begin{tabular}{cccc} 
(Inter3) & & \\
\hline Variables & Parameter & t-test & -level \\
\hline Innov1 & 0,26 & $-0,37$ & 0,71 \\
Innov2 & 38,95 & 2,01 & 0,04 \\
Innov3 & 2,24 & 0,35 & 0,73 \\
Innov4 & $-0,002$ & $-1,20$ & 0,23 \\
Innov5 & 0,20 & 0,83 & 0,40 \\
Innov6 & $-0,001$ & $-1,09$ & 0,28 \\
_cons & $316,89 \quad R^{2}=0,66$ & 2,11 & 0,03 \\
& \multicolumn{2}{c}{$X^{2=40,8 \text { at } p=0,0062}$} & \\
\hline
\end{tabular}

Sources: developed by the authors.

Table 5. The results of a regression model with random effects, which reflects the functional relationship between the level of innovative development of countries and Trade balance (Inter9)

\begin{tabular}{cccc}
\hline Variables & Parameter & t-test & p-level \\
\hline Innov1 & $-0,59$ & $-1,29$ & 0,197 \\
Innov2 & $-3,19$ & $-0,26$ & 0,795 \\
Innov3 & $-7,25$ & $-1,76$ & 0,079 \\
Innov4 & 0,0009 & 0,76 & 0,446 \\
Innov5 & 0,33 & 2,07 & 0,038 \\
Innov6 & 0,0003 & 0,50 & 0,618 \\
cons & $-83,89 \quad R^{2=0,48}$ & 0,89 & 0,376 \\
& \multicolumn{2}{c}{$X^{2=41,37 \text { at } p=0,0006}$} & \\
\end{tabular}

Sources: developed by the authors.

Table 6. The results of a regression model with random effects, which reflects the functional relationship between the level of innovative development of countries and External debt (Inter12)

\begin{tabular}{cccc}
\hline Variables & Parameter & t-test & p-level \\
\hline Innov1 & $-2,58$ & $-3,49$ & 0,000 \\
Innov2 & 6,81 & 0,30 & 0,766 \\
Innov3 & $-28,32$ & $-2,78$ & 0,005 \\
Innov4 & $-0,004$ & $-1,28$ & 0,201 \\
Innov5 & $-1,19$ & $-3,52$ & 0,000 \\
Innov6 & $-0,0009$ & $-0,85$ & 0,397 \\
_cons & $273,65 \quad R^{2=0,83}$ & 1,76 & 0,079 \\
& \multicolumn{2}{c}{$X^{2=56,54 \text { at } p=0,0000}$} & \\
\end{tabular}

Sources: developed by the authors.

Thus, the nature of the functional relationship between the level of innovation development and the three indicators of international economic activity can be described by the following dependencies:

- with an increase in the volume of research and development expenditure (Innov2) by 1\%, the value of Trade openness will increase by $38.95 \%$; 
- increase of High technology exports as a share of manufactured exports (Innov5) by 1\% will increase Trade balance by $0.33 \%$ and reduce External debt by $1.19 \%$;

- with the increase of the Innovation index (Innov1) per unit, the volume of External debt will decrease by $2.58 \%$;

- with an increase in Information technology exports (Innov3) by 1\%, and External debt will reduce by $28.32 \%$.

Conclusions. Under the purpose of the article, which was to confirm the hypothesis of functional links between foreign trade and investment activities of countries and the level of innovative development of the country according to the level of economic development, a structural model and three multifactor regression models with random effects for panel data were built. of the CIS member states and the nearest neighbouring countries for the period 2011-2018. The results of the study empirically confirm the above hypothesis regarding the closeness of the statistically significant relationship between the studied indicators - determinants of international economic activity and the level of innovative development. In particular, three latent variables were formed, formed from a set of indicators selected by the method of main components, INNOV, which includes Innovation index, Information technology exports, High technology exports2; INTER, which includes Trade openness, Trade balance, External debt and GOV, which accumulates the following indicators - GDP per capita, Inflation, Real interest rate. The main interest in the study was the nature of the relationship between the variables INNOV and INTER. The results of structural modelling confirmed the presence of a statistically significant functional relationship between the level of innovative development and international economic activity of the studied countries. Besides, it was found that it is an innovative development that has a stronger direct impact on the formation of international economic relations, which is confirmed by the calculated regression coefficient. In connection with the results obtained during the structural modelling, the second part of the article is devoted to the identification of the direct identification of the impact of innovative development of countries on their international economic activity in terms of specific indicators. Thus, three multifactor regression models with random effects were constructed, where six indicators of innovative development acted as independent variables, and three indicators, which were part of the latent INTER variable, acted as a stagnant variable. According to the results, the positive statistically significant impact on the indicators of international economic activity of the CIS member states and neighbouring countries has Innovation index, Research and development expenditure, Information technology exports, High technology exports as a percentage of manufactured exports. Thus, to establish successful international economic relations between the CIS member states and neighbouring countries, it is necessary to continue to increase the number of allocated funds within the country for the development of innovative activities, which will automatically provoke the IT export market.

\section{References}

Agnihotri, A., \& Arora, S. (2019). Study of Linkages Between Outward Foreign Direct Investment (OFDI) and Domestic Economic Growth: an Indian Perspective. Financial Markets, Institutions and Risks, 3(1), 43-49. [Google Scholar] [CrossRef].

Ahmmed, M. M., \& Salim, Z. R. (2019). The Impact of Internet on the Youth Leadership. Business Ethics and Leadership, 3(3), 99-106. [Google Scholar] [CrossRef]

Akimova, L. M., Akimov, O. O., \& Liakhovich, O. O. (2017). State regulation of foreign economic activity. Scientific bulletin of Polissia, 1(4 (12)), 98-103.. [Google Scholar]

Akimova, L., Akimov, O., Mihus, I., Koval, Y., \& Dmitrenko, V. (2020). Improvement of the methodological approach to assessing the impact of public governance on ensuring the economic security of the state. Financial and credit activity: problems of theory and practice, 4(35), 180-190. [Google Scholar]

Bardy, R., \& Rubens, A. (2019). The Public Good of Internet Usage and its Social Impact: A Business Ethics Approach. Business Ethics and Leadership, 3(2), 63-71. [Google Scholar] [CrossRef] 
Bilan, Y., Brychko, M., Buriak, A., \& Vasilyeva, T. (2019a). Financial, business and trust cycles: The issues of synchronization. Zbornik Radova Ekonomskog Fakultet au Rijeci, 37(1), 113-138. [Google Scholar] [CrossRef]

Bilan, Y., Rubanov, P., Vasylieva, T., \& Lyeonov, S. (2019b). The influence of industry 4.0 on financial services: Determinants of alternative finance development. Polish Journal of Management Studies, 19(1), 70-93. [Google Scholar] [CrossRef]

Brychko, M., Bilan, Y., Lyeonov, S., \& Mentel, G. (2020). Trust crisis in the financial sector and macroeconomic stability: a structural equation modelling approach. Economic Research-Ekonomska Istraživanja, 1-28. [Google Scholar] [CrossRef]

Buchynska, O., Davlikanova, O., Hofstetter, H., \& Lylyk, L. (2020). The Ukraine-Based Employers' Awareness of Dual Studies and Willingness to Engage into the Implementation of Education Innovations. Business Ethics and Leadership, 4(3), 137-144. [Google Scholar] [CrossRef].

Delanoy, N., \& Kasztelnik, K. (2020). Business Open Big Data Analytics to Support Innovative Leadership and Management Decision in Canada. Business Ethics and Leadership, 4(2), 56-74. [Google Scholar] [CrossRef]

Gatsi, J. G. (2020). Effects of International and Internal Remittanaces on Financial Inclusion in Ghana. Financial Markets, Institutions and Risks, 4(3), 109-123. [Google Scholar] [CrossRef]

Goncharenko, T. (2020). From Business Modelling to the Leadership and Innovation in Business: Bibliometric Analysis (Banking as a Case). Business Ethics and Leadership, 4(1), 113-125. [Google Scholar] [CrossRef]

Ibragimov, Z., Lyeonov, S., \& Pimonenko, T. (2019a). Green investing for SDGS: EU experience for developing countries. Economic and Social Development: Book of Proceedings, 867-876. [Google Scholar]

Ibragimov, Z., Vasylieva, T., \& Lyulyov, O. (2019b). The national economy competitiveness: effect of macroeconomic stability, renewable energy on economic growth. 37th International Scientific Conference on Economic and Social Development - «Socio Economic Problems of Sustainable Development», 878-887. [Google Scholar]

Kasztelnik, K., \& Brown, D. (2020). The Observational Socio-Economic Study and Impact on the International Innovative Leadership in the United States. SocioEconomic Challenges, 4(4), 63-94. [Google Scholar] [CrossRef].

Kharazishvili, Y., Kwilinski, A., Grishnova, O., \& Dzwigol, H. (2020). Social Safety of Society for Developing Countries to Meet Sustainable Development Standards: Indicators, Level, Strategic Benchmarks (with Calculations Based on the Case Study of Ukraine). Sustainability, 12(21), 8953. https://doi.org/10.3390/su12218953

Kuzmenko, O., Lieonov, S., \& Kashcha, M. (2020) Financial, economic, environmental and social determinants for Ukrainian regions differentiation by the vulnerability level to COVID-19. Financial and credit activity-problems of theory and practice, 3, 34 . [Google Scholar]

Kuznyetsova A. Ya., Zherebylo I. V., Klipkova O. I., Kozmuk N. I. (2019). Creation of the value of national enterprises with the help of the innovation centers in the cluster formations. Financial and credit activities: problems of theory and practice, 2(29), 391-402. [Google Scholar] [CrossRef]

Kwilinski, A., \& Kuzior, A. (2020). Cognitive Technologies in the Management and Formation of Directions of the Priority Development of Industrial Enterprises. Management Systems in Production Engineering, 28(2), 119-123 http://doi.org/10.1515/mspe-2019-0020

Leonov, S., Demkiv, Y. M., \& Samusevych, Y. (2018). Evaluation of banking services quality on the servqual approach basis: modern interpretation. Financial and Credit Activity-Problems of Theory and Practice, 2(25), 47-55. [CrossRef]

Lyeonov, S., Kuzmenko, O., Bozhenko, V., Mursalov, M., Zeynalov, Z., \& Huseynova, A. (2020). Forecasting the risk of money laundering through financial intermediaries. Financial and credit activity: problems of theory and practice, 4(35), 191-201. [Google Scholar] [CrossRef].

Lyulyov, O., Pimonenko, T., Kwilinski, A., Dzwigol, H., Dzwigol-Barosz, M., Pavlyk, V., \& Barosz, P. (2021). The Impact of the Government Policy on the Energy Efficient Gap: The Evidence from Ukraine. Energies, 14(2), 373. [Google Scholar] [CrossRef].

Marcel, D. T. A. (2019). Impact of the Foreign Direct Investment on Economic growth on the Re-public of Benin. Financial Markets, Institutions and Risks, 3(2), 69-78. [Google Scholar] [CrossRef].

Mujtaba, B. G., Pellet, P. F., \& Sungkhawa, J. (2019). Understanding the Interconnectedness of International Trade Theories: A Case in Point of Cuba in Transition. SocioEconomic Challenges, 3(1), 27-41. [Google Scholar] [CrossRef]

Myroshnychenko, I., Makarenko, I., Smolennikov, D., \& Buriak, A. (2019). The approach to managing corporate social and environmental responsibility in manufacturing. TEM Journal, 8(3), 740. [Google Scholar]

Rausser, G., Strielkowski, W., Bilan, Y., \& Tsevukh, Y. (2018). Migrant remittances and their impact on the economic development of the Baltic States. Geographica Pannonica, 22(3), 165-175. [CrossRef]

Samoilikova, A. (2020). Financial Policy of Innovation Development Providing: The Impact Formalization. Financial Markets, Institutions and Risks, 4(2), 5-15. [Google Scholar] [CrossRef].

Shuquan H. (2018). The Transmission of International Food Commodity Prices to China. Financial Markets, Institutions and Risks, 2(3), 52-61. [Google Scholar] [Google Scholar]

Strielkowski, W., \& Höschle, F. (2016). Evidence for economic convergence in the EU: The analysis of past EU enlargements. Technological and Economic Development of Economy, 22(4), 617-630. [CrossRef

Strielkowski, W., Lisin, E., \& Gryshova, I. (2016). Climate Policy of the European Union: What to Expect from the Paris Agreement? Romanian Journal of European Affairs, 16(4), 68-77. [Google Scholar]

Tiutiunyk, I. V. (2018) Determination of Priority Financial Instruments of Regional Sustainable Development. International Journal of Ecology \& Development, 33(3), 11-18. [Google Scholar] 


\section{A., Huseynov, T., Illiashenko, I., Petroke. Management of Innovation Development: Critical Evaluation of the}

International Economic Relations

Umadia Sr, K., \& Kasztelnik, K. (2020). The Financial Innovative Business Strategies of Small to Medium Scale Enterprises in Developing Country and Influence for the Global Economy Performance. SocioEconomic Challenges, 4(3), 20-32. [Google Scholar] [CrossRef].

Vorontsova, A., Vasylieva, T., \& Mayboroda, T. (2020). The justification of the efficiency of financial support of education in the context of the national economy development. Financial and credit activity: problems of theory and practice, 3(34), 312-321. [Google Scholar] [CrossRef].

Vysochyna, A., Stoyanets, N., Mentel, G., \& Olejarz, T. (2020). Environmental determinants of a country's food security in short-term and long-term perspectives. Sustainability, 12(10), 4090. [Google Scholar] [CrossRef].

Yarovenko, H. M., Kuzmenko, O. V., \& Stumpo, M. (2020). DEA-Analysis Of The Effectiveness Of The Country's Information Security System. SocioEconomic Challenges, 4(3), 142-153. [Google Scholar] [CrossRef].

Zolkover, A., \& Renkas, J. (2020). Assessing The Level Of Macroeconomic Stability Of EU Countries. SocioEconomic Challenges, 4(4), 175-182. [Google Scholar] [CrossRef].

Гусейнов Илькин Адыль оглы, Азербайджанський Державний Економічний Університет, Азербайджан;

Тетяна Ілляшенко, к.е.н., Сумський державний університет, Україна;

€ва Петроке, Каунаський технологічний університет, Литва.

Управління інноваційним розвитком: критична оцінка міжнародних економічних відносин

Геополітична стабільність країни завжди була основою забезпечення сталого економічного розвитку. При цьому процеси трансформації, зумовлені науково-технічним прогресом, інтенсивністю глобальних інновацій та тенденціями глобалізації, спонукали країни перейти на новий рівень розвитку. У цій статті узагальнено аргументи та контраргументи в рамках наукової дискусії щодо ролі та можливостей країн СНД у формуванні основи для інноваційного розвитку. Автори зазначили, що країни СНД та їх найближчі сусіди є міжнародними центрами, через які проходять важливі транспортні та комунікаційні шляхи з Азії до Європи. Виходячи з цього, забезпеченість широким спектром різноманітних запасів сировини привертає увагу світової спільноти до побудови окремого вектору економічних відносин із цими країнами. Основною метою дослідження є підтвердження гіпотези про функціональні зв'язки між зовнішньою торгівлею, інвестиційною діяльністю країн та рівнем інноваційного розвитку країни відповідно до рівня економічного розвитку. Методологічним інструментарієм дослідження є методи кореляційно-регресійного аналізу та одночасні структурні рівняння, що дозволяють формалізувати як явні, так і приховані взаємозв'язки між досліджуваними об'єктами. Періодом дослідження є 2011-2018рр., оскільки для цього періоду доступні необхідні статистичні дані для проведення аналізу. У рамках дослідження, масив вхідних даних представлений у формі регресорів, які визначають рівень країн, що інноваційно розвиваються, а також трьох залежних змінних (регресантів), які вказують на динаміку зовнішньоторговельного обороту, ведення бізнесу та загальні внутрішньоекономічні умови. Для побудови структурної моделі застосовано як залежні, так і незалежні змінні кожного визначеного блоку. Результати дослідження можуть бути корисними для інноваційних агентств, створених при Міністерств транспорту, зв'язку та високих технологій цих країн, що сприяють придбанню сучасних технологій та технологічних рішень місцевими суб'єктами господарювання.

Ключові слова: міжнародні економічні відносини, інвестиції, експорт, імпорт, зовнішньоторговельний оборот, країни СНД, регресійний аналіз, структурне моделювання. 